\begin{tabular}{l|l|l|}
\cline { 2 - 3 } CRITICAL & $\begin{array}{l}\text { Western Ghats } \\
\text { PARTNERSTIP FUND }\end{array}$ & Special Series \\
\hline
\end{tabular}

\section{RARE FUNGUS FEEDING DARKLING BEETLE, BYRSAX CORNUTUS FABRICIUS, 1792 (COlEOPTERA: TeNebrIONIDAE: BOLITOPHAGINI) FROM THE WESTERN GHATS, INDIA}

\section{Arunraj ${ }^{1}$, Sabu K. Thomas ${ }^{2}$ \& Ottó Merkl ${ }^{3}$}

1,2 Litter Entomology Research Unit, Post Graduate and Research Department of Zoology, St. Joseph's College, Devagiri, Kozhikode, Kerala, India.

${ }^{3}$ Hungarian Natural History Museum, Baross utca 13, H-1088 Budapest, Hungary.

${ }^{1}$ rajcarun@gmail.com, ${ }^{2}$ sabukthomas@gmail.com (corresponding author), ${ }^{3}$ merkl@zoo.zoo.nhmus.hu

Beetles of the tribe Bolitophagini are associated with fruiting bodies (conks) of bracket fungi throughout their lives. The larvae always tunnel inside the conk and feed on its tissue while adults usually are surface feeders; consuming the spores after sweeping them with their mouthparts to the mouth. The adults are mainly seen on the surface of the hymenium (the fertile layer of the fruiting body), although some species hide in the larval tunnels during the day. Bolitophagines usually feed on the same fruiting body associated with dead trees and develop in it until the fungi are completely destroyed and decayed (Jung et al. 2007).

Members of a genus of the tribe, Byrsax, live in the fruiting body of various bracket fungi, including the wood-decaying white-rot bracket fungus Ganoderma applanatum (Persoon) Patouillard 1889, popularly known as Artist's Conk (Hawkeswood 2003).

Distribution of the genus stretches across the Palaearctic (Russian Far East, Japan, Korea, China), Oriental (India, Sri Lanka, Vietnam, Indonesia, Malaysia, Philippines) and Australian (eastern Australia, Papua New Guinea) realms (Gebien 1939; Kaszab 1979a,b, 1980; Jung et al. 2007; Löbl et al. 2008; Matthews \& Bouchard 2008). Cryptic brownish-grey coloration of adults that matches the color of host fungi and secretive habits of Byrsax species lead them to be often overlooked by collectors (Hawkeswood 2003). Twenty seven species of the genus Byrsax are known worldwide (Gebien 1939; Löbl et al. 2008). Two species namely, Byrsax cornutus Fabricius, 1792 (Gebien 1925) and B. tuberculatus Gravely, 1915 (Kaszab 1979a) are reported from India (Image 1). Byrsax tuberculatus (Image 2 ) is known to occur in Nepal, India (Arunachal Pradesh, Kerala: Kumily), Sri Lanka (Colombo, Peradeniya, Kandy, Dikoya, Kitulgala, Galle), Thailand, Vietnam, Malaysia, Java, Borneo and the Philippines. Byrsax cornutus occurs in India and Sri Lanka (Image 1). The present work includes a first report of Byrsax cornutus from the Western Ghats with diagnostic description, key to the two Byrsax species from India along with an illustration of their distribution from the Indian subcontinent.

Materials and Methods: Specimens were collected with light traps and from leaf litter present close to a decaying log with rich growth of Ganoderma applanatum during 2006-2009 period. Identification up to the genus

DOI: http://dx.doi.org/10.11609/JoTT.o3188.4608-11 | ZooBank: urn:Isid:zoobank.org:pub:16CD19AE-C3F0-45E0-84E0-1BD52929B718

Editor: Dr. Partha Pratim Bhattacharjee, Tripura University, Suryamaninagar, India

Date of publication: 26 July 2013 (online \& print)

Manuscript details: Ms \# o3188 | Received 01 May 2012 | Final received 27 June 2013 | Finally accepted 02 July 2013

Citation: Arunraj, C., S.K. Thomas \& O. Merkl (2013). Rare fungus feeding Darkling Beetle, Byrsax cornutus Fabricius, 1792 (Coleoptera: Tenebrionidae: Bolitophagini) from the Western Ghats, India. Journal of Threatened Taxa 5(11): 4608-4611; http://dx.doi.org/10.11609/JoTT.03188.4608-11

Copyright: (c) Arunraj et al. 2013. Creative Commons Attribution 3.0 Unported License. JoTT allows unrestricted use of this article in any medium, reproduction and distribution by providing adequate credit to the authors and the source of publication.

Funding: Department of Science and Technology, Government of India (DST-INSPIRE Fellowship)

Competing Interest: None.

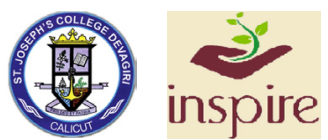

Acknowledgements: Financial assistance provided by Department of Science \& Technology (DST), Government of India (DST-INSPIRE Fellowship) to the first author is gratefully acknowledged. We thank T. Németh, expert on Hungarian Elateridae, Hungarian Natural History Museum for digital images, and P.M. Nirdev, St. Joseph's College, Kozhikode, for assistance during field trips.

The publication of this article is supported by the Critical Ecosystem Partnership Fund (CEPF), a joint initiative of l'Agence Française de Développement, Conservation International, the European Commission, the Global Environment Facility, the Government of Japan, the MacArthur Foundation and the World Bank. 


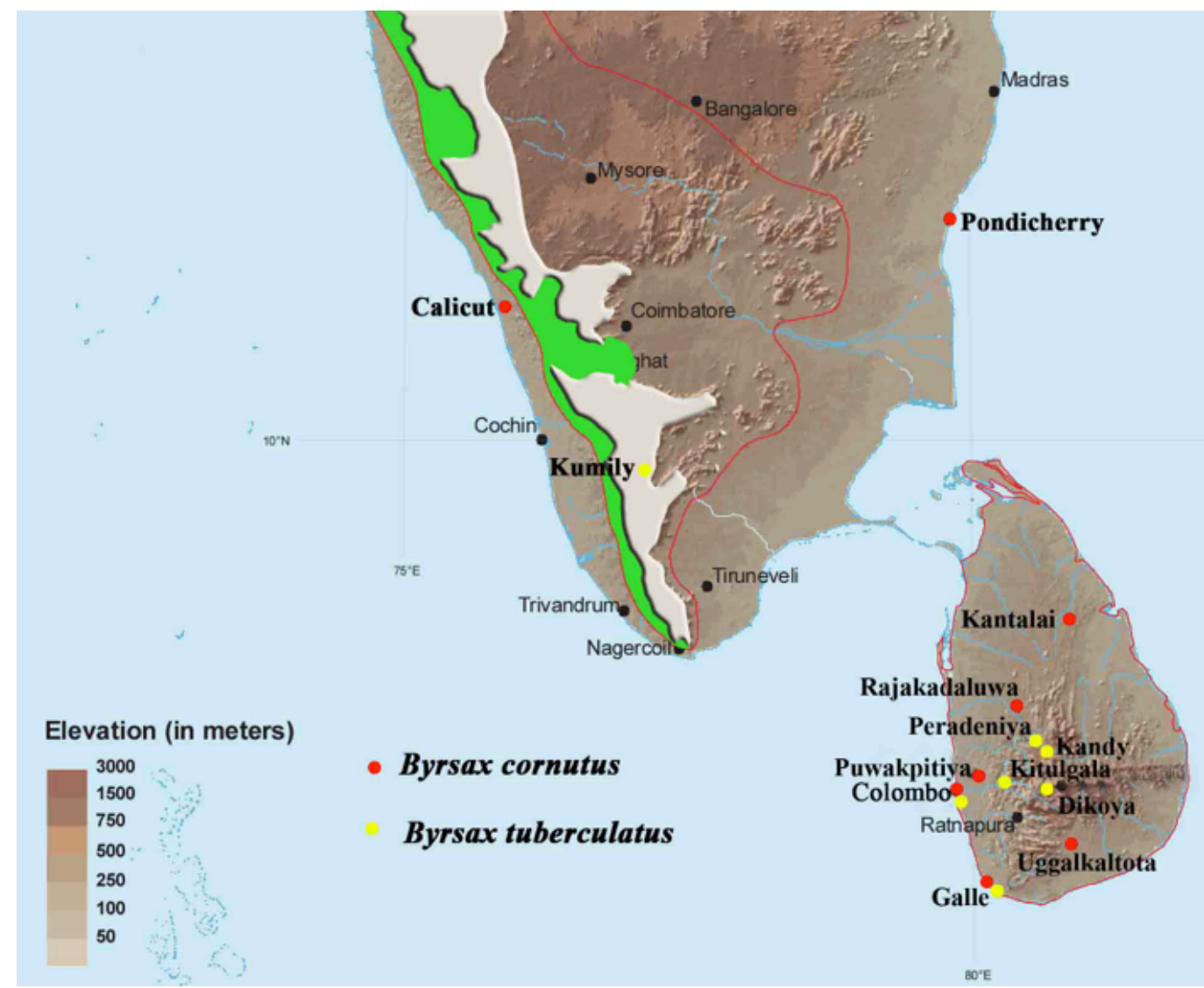

Image 1. Map of the Western Ghats and Sri Lanka indicating distribution of Byrsax cornutus and B. tuberculatus.

and species level was done with the key of Gebien (1925) and by comparing with verified specimens in the Coleoptera Collection of the Hungarian Natural History Museum, Budapest, Hungary. Specimens from the present study are deposited in the coleopteran collections of Litter Entomology Research Unit, St. Joseph's College, Devagiri, Calicut (SJC).

\section{Byrsax cornutus (Fabricius, 1792) (Image 3)}

Synonyms: Byrsax horridus Olivier, 1795; Byrsax tuberculifer Motschulsky, 1863 (Gebien 1925).

Materials Examined: BC-2009-01 SJC, 22.vii.2009, one female, Omassery, Kerala, India $\left(11.3666^{\circ} \mathrm{N}\right.$ \& $75.9333^{\circ} \mathrm{E} ; 22 \mathrm{~m}$ elevation), light attracted specimen, coll. C. Arunraj (Image 3); BC-2006-02 SJC, 06.xii.2006, one male, Malaparamba $\left(11.3000^{\circ} \mathrm{N} \& 75.8500^{\circ} \mathrm{E} ; 13 \mathrm{~m}\right.$ elevation), litter collection, Berlese extraction, coll. K.V. Vinod.

Body: Oval, strongly convex, strongly sculptured and tuberculate. usually covered with lighter brown encrustation of fungal spores. Spore mass usually filling and obscuring dorsal punctation of pronotum and elytra.

Color: Blackish-brown.

Head: Frons of male with a pair of curved and flattened horns; length of horn varying from shorter than interocular distance to as long as length of pronotum. Female without horns. Eyes large, oval, excised by frontal canthus. Labrum subquadrate, setal pattern symmetrical, antennae barely longer than head width, antennomeres gradually expanding apically, last seven antennomeres forming a large asymmetrical club. Mandibles bidentate with long teeth, molar surface with fine striations. Maxilla without lacinial uncus, palpi with apical segments fusiform. Mentum trapezoidal.

Pronotum: Surface with coarse punctation and with strong protuberances and tubercles varying in size, lateral parts strongly explanate, sides strongly serrate, with a semicircular excision near posterolateral angles.

Elytra: Highly convex, with coarse punctation and strong protuberancesand tubercles. Threeprotuberances on each elytron much larger and arranged in two parallel rows, other tubercles much smaller. Lateral parts strongly explanate, sides strongly serrate.

Venter: Procoxal cavities closed internally and 

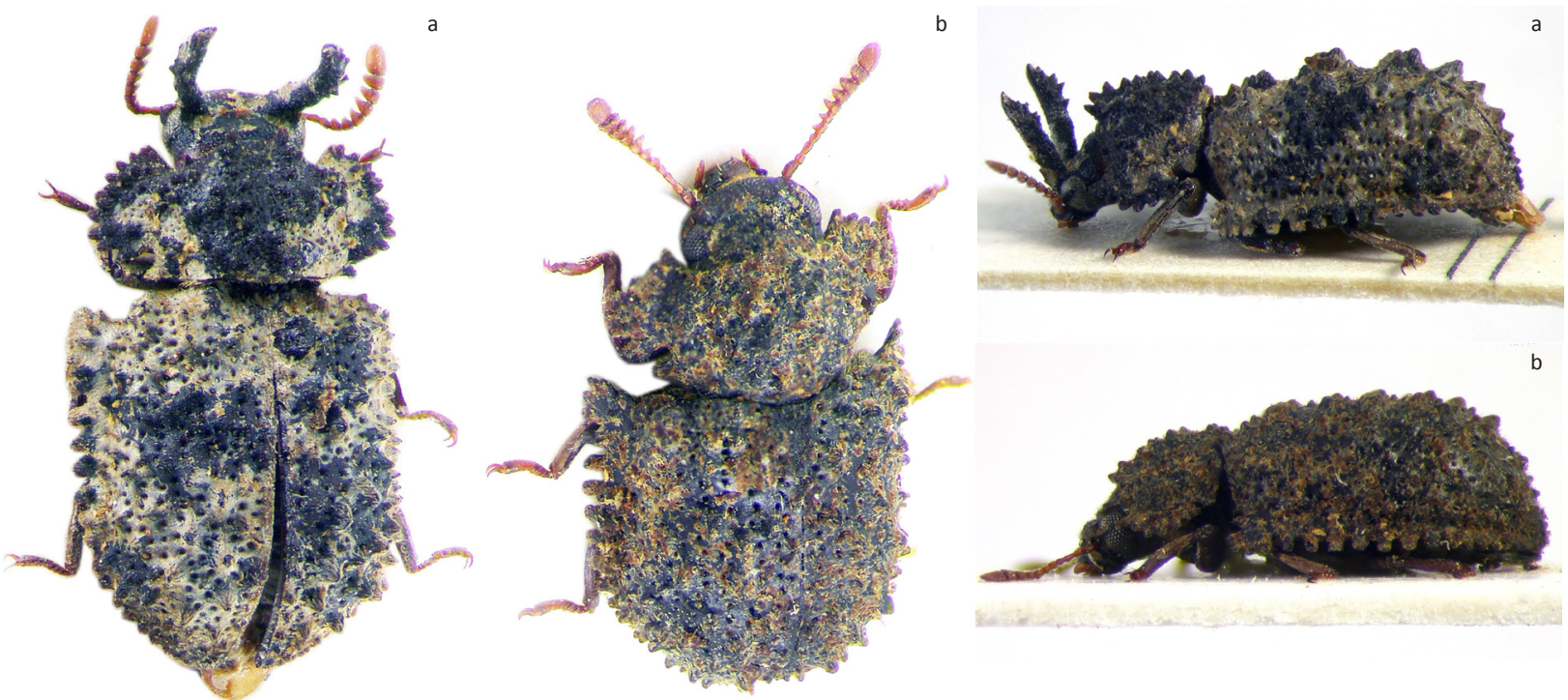

Image 2. Byrsax tuberculatus. a - male; b-female. ㄷ Tamás Németh, Budapest
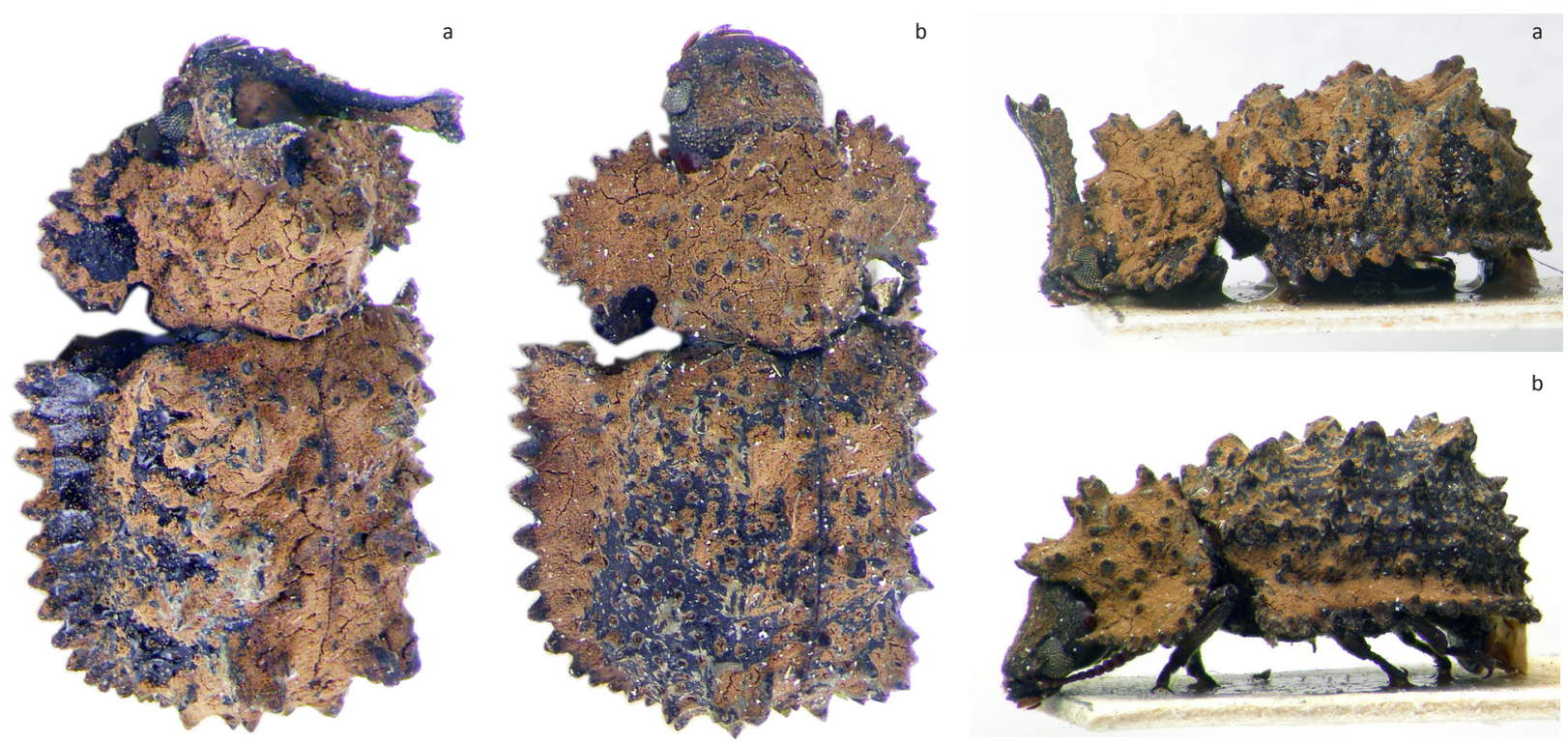

Image 3. Byrsax cornutus. a - male; b - female. C Tamás Németh, Budapest

externally. Mesocoxal cavities partly closed by mesepimeron. Membranes present between last three abdominal ventrites.

Legs: Not fossorial, tibiae with longitudinal carinae, subapical tarsomeres very short, obliquely truncate, plantar surfaces with long sparse setae. Tarsal formula 4-4-4 (in contrast with 5-5-4 as normal in the family Tenebrionidae).

Measurements (in $\mathrm{mm} ; 1$ male and 1 female): $\mathrm{TL}=$ 6-6.2, $\mathrm{TW}=2.6-2.9, \mathrm{PL}=2.5-2.8, \mathrm{PW}=1.9-2.1, \mathrm{EL}=$ 4.2-4.4.

Habitat: On fruiting bodies of bracket fungi, also leaf litter around them; attracted to light.

Distribution: India (Kerala: Kozhikode; Pondicherry); Sri Lanka (Colombo, Kantalai, Rajakadaluwa, Puwakpitiya, Uggalkaltota, Galle). Occurrence in Sumatra (Gebien 1925) is doubtful.

Remarks: Byrsax cornutus is active after sunset. During the day it remains motionless, but starts walking upon exposure to sunlight to find shelter. On handling it produces a very strong, distinctive odour caused by the secretion of abdominal defensive glands.

Dorsal surface of the beetle is strongly sculptured and tuberculate, and capable of holding a compact layer of 


\section{Key to species of Byrsax from India}

Each elytron with three prominent, large protuberances and numerous much smaller tubercles; six protuberances on two elytra arranged in two parallel rows. Fore and middle protuberances are longitudinal, hind one transverse. Pronotum with a pair of large, three-or four-peaked tubercles situated at middle, and two pairs of smaller tubercles before scutellum. Body longer $(6.0-7.5 \mathrm{~mm})$ B. cornutus

Elytra with numerous smaller tubercles subequal in size. Pronotum with numerous small tubercles, the largest situated just behind anterior margin. Body shorter $(4.5-5.5 \mathrm{~mm})$ B. tuberculatus

spores of the host fungi. This, along with the body form, provides a perfect camouflage; the motionless beetle looks like a simple hump and is very hard to recognize in its environment of rugged fruiting bodies and parts of rotten wood.

\section{REFERENCES}

Gebien, H. (1925). Die Tenebrioniden (Coleoptera) des indomalayischen Gebietes, unter Beruecksichtigung der benachbarten Faunen, I. Einleitung sowie die Gattung Byrsax Pascoe. The Philippine Journal of Science 26(1): 67-94.

Gebien, H. (1939). Katalog der Tenebrioniden. Teil II. Mitteilungen der Münchener Entomologischen Gesellschaft 29: 443-474, 739-770 [466-529].

Hawkeswood, T.J. (2003). New host records for adults of some fungus-feeding beetles (Coleoptera) from New South Wales and
Queensland, Australia. Calodema 1: 7-11

Jung, B.H., S.Y. Kim \& J.I. Kim (2007). Taxonomic review of the tribe Bolitophagini in Korea (Coleoptera: Tenebrionidae: Tenebrioninae). Entomological Research 37: 190-196; http://dx.doi.org/10.1111/ j.1748-5967.2007.00111.x

Kaszab, Z. (1979a). Tenebrioniden aus Südindien (Coleoptera). Acta Zoologica Academiae Scientiarum Hungaricae 25: 259-310.

Kaszab, Z. (1979b). Faunistik der Tenebrioniden von Sri Lanka. Folia entomologica hungarica 32(2): 43-128.

Kaszab, Z. (1980). Angaben zur Kenntnis der Tenebrioniden Nordvietnams (Coleoptera). Annales historico-naturales Musei nationalis hungarici 72 : 169-221.

Löbl, I., O. Merkl, K. Ando, P. Bouchard, M. Lillig, K. Masumoto \& W. Schawaller (2008). Tenebrionidae, pp. 105-352. In: Löbl, I. \& A. Smetana (eds). Catalogue of Palaearctic Coleoptera - Volume 5. Tenebrionoidea. Apollo Books, Stenstrup, 670pp.

Matthews, E.G. \& P. Bouchard (2008). Tenebrionid Beetles of Australia. Australian Biological Resources Study, Canberra, 398pp. 